\title{
Conference News
}

\section{INTERNATIONAL CONFERENCE ON METALLURGICAL COATINGS}

April 3-7, 1978. To be held in San Francisco, California.

This conference is sponsored by the Vacuum Metallurgy Division, together with the Thin Film Division of the American Vacuum Society Inc. For further information, please contact:

R. F. Bunshah Conference Chairman 6532 Boelter Hall 405 Hilgard Avenue University of California Los Angeles. CA 90024 U.S.A.

21st SALON INTERNATIONAL DES COMPOSANTS ELECTRONIQUES (INTERNATIONAL ELECTRONIC COMPONENTS EXHIBITION)

April 3-8, 1978. To be held in Paris at the Exhibition Park, Porte de Versailles, Halls 1 and 2.

For further information, please contact:

Société pour la Diffusion des Sciences et des Arts

(S.D.S.A.)

20 rue Hamelin

75116 PARIS

France

\section{INTERNATIONAL CONFERENCE ON SOLID FILMS AND SURFACES}

To be held at Toshi Centre Hall, Tokyo, Japan. 6-8 July, 1978.

For further information please contact:

Professor R. Ueda

Department of Applied Physics

School of Engineering and Science

Waseda University

4-170 Nishi-Ohkubo, Shinjuku-ku

TOKYO 160

Japan

\section{TH INTERNATIONAL THIN FILMS CONGRESS}

This Congress will be held at the University of Technology, Loughborough, 11-15 September, 1978. The Congress is being organised by the Institute of Physics, London and the theme will be the properties of Thin Films in relation to structure. Emphasis will therefore be placed on the correlation between the electrical, magnetic, mechanical and optical properties of thin films and their crystalline, morphological, defect and compositional structure.

Although papers dealing with correlated properties are preferred, those which primarily exploit a single aspect will not necessarily be excluded. In addition, papers are solicited on Thin Film Devices and other Thin Film applications.

For further information, please contact the Conference Secretary.

Dr C. J. Todd

Post Office Research Centre

Martlesham Heath

IPSWICH

Suffolk. IP5 7RE

U.K.

\section{ELECTRONICA 1978}

9-15 November, 1978. To be held in Munich at the International Electronic Centre.

For further information please contact:

Herr H. J. Prieur

Internationales Elektronik Zentrum

D-8000 MUNCHEN 12

Postfach 121009

Theresienhöhe 13 GERMANY 

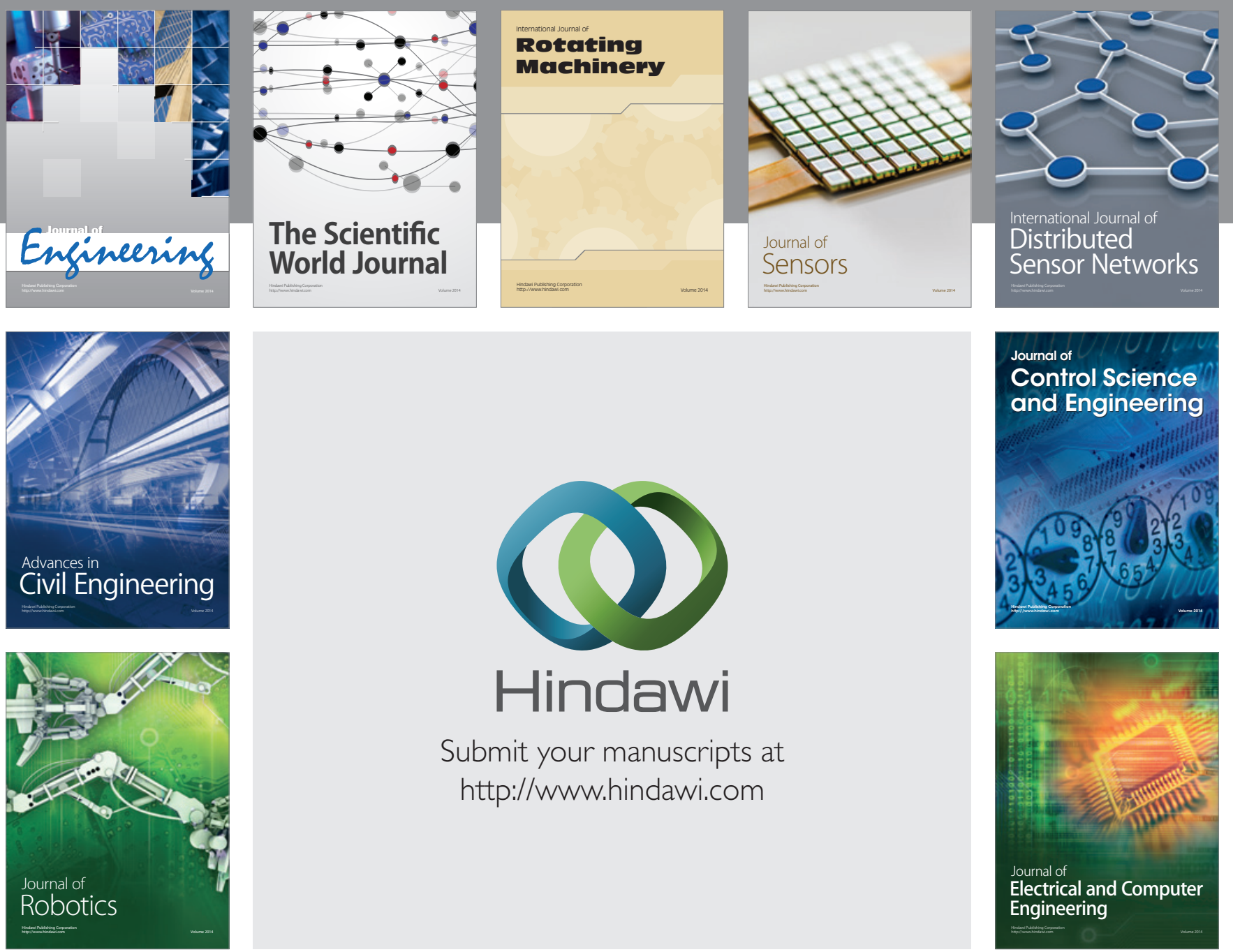

Submit your manuscripts at

http://www.hindawi.com
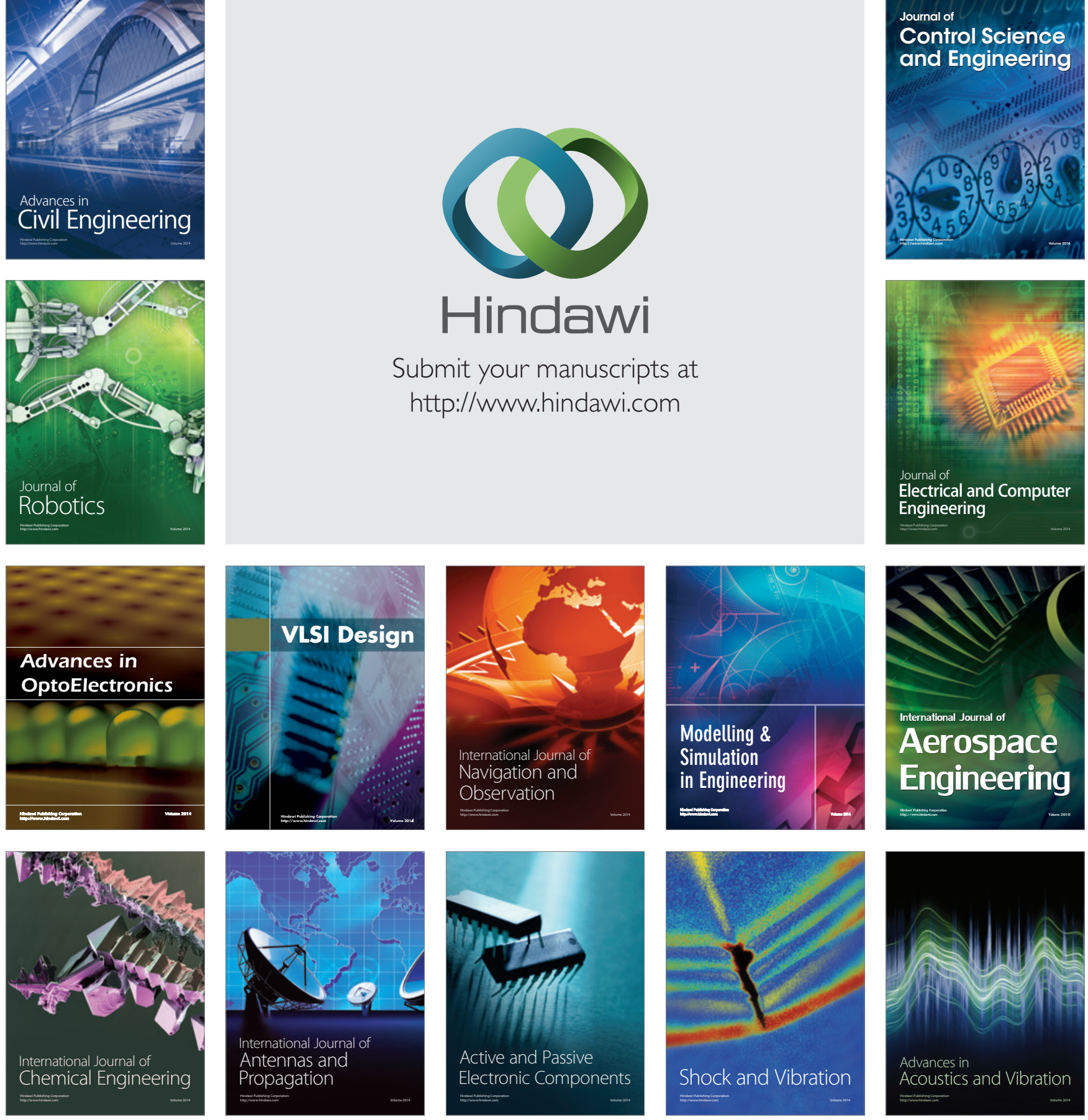